\title{
Lower Vibrio spp. abundances in Zostera marina leaf canopies suggest a novel ecosystem function for temperate seagrass beds
}

\author{
Thorsten B. H. Reusch ${ }^{1,4}(1)$ Philipp R. Schubert ${ }^{1} \cdot$ Silke-Mareike Marten ${ }^{1} \cdot$ Diana Gill ${ }^{1} \cdot$ Rolf Karez $^{2} \cdot$ Kathrin Busch $^{3}$. \\ Ute Hentschel ${ }^{3,4}$
}

Received: 19 April 2021 / Accepted: 25 August 2021

(C) The Author(s) 2021

\begin{abstract}
Seagrasses, a polyphyletic group of about 60 marine angiosperm species, are the foundation of diverse and functionally important marine habitats along sheltered sedimentary coasts. As a novel ecological function with high societal relevance, a role of the seagrass leaf canopy for reducing potentially harmful bacteria has recently been hypothesized in tropical regions, but data for temperate regions are lacking. Here, we tested whether or not the abundance of general bacteria and more specifically, those belonging to the genus Vibrio were reduced within temperate Zostera marina (eelgrass) meadows compared to adjacent sand flats and sampled 5 sites in the south-western Baltic Sea using SCUBA. Compared to non-vegetated area, we found an average reduction of 39\% for all Vibrio and 63\% for the potentially harmful V. vulnificus/cholerae subtype based on robust plate counting data on Vibrio selective agar. The underlying mechanism of the reduction in bacterial load is currently elusive and clearly merits further study. Our results underline the critical importance of seagrasses in maintaining shallow water ecosystem functioning including water quality and provide further motivation for their protection and restoration.
\end{abstract}

\section{Introduction}

Marine angiosperms, or seagrasses, are the foundation of some of the most valuable coastal marine ecosystems, seagrass beds (Hemminga and Duarte 2000). As ecosystem engineers, their presence turns sedimentary bottoms with mostly infauna into a habitat featuring a rich diversity of

Responsible Editor: D. Ngug.

Reviewers: K. McMahon and J. Padilla-Gamino.

Thorsten B. H. Reusch

treusch@geomar.de

1 Division of Marine Ecology, Marine Evolutionary Ecology, GEOMAR Helmholtz-Centre for Ocean Research Kiel,, Düsternbrooker Weg 20, 24105, Kiel, Germany

2 State Agency for Agriculture, Environment, and Rural Areas Schleswig-Holstein (LLUR), Hamburger Chaussee 25, 24220 Flintbek, Germany

3 Division of Marine Ecology, Marine Symbioses, GEOMAR Helmholtz-Centre for Ocean Research Kiel, Düsternbrooker Weg 20, 24105 Kiel, Germany

4 Faculty of Mathematics and Natural Sciences, Christian-Albrechts University of Kiel, Christian-Albrechts-Platz 4, 24118 Kiel, Germany associated animals and plants, along with substantial ecosystem services such as nursery areas, coastal protection and local carbon sequestration (Fourqurean et al. 2012; Heckwolf et al. 2021). Among the many ecological services associated with seagrasses, the reduction of potentially harmful bacteria in the water column has recently been described for tropical seagrass beds (Lamb et al. 2017). Lamb et al. (2017) showed that both, the abundance of possible human pathogenic bacteria as well as bacterial strains infecting marine invertebrates, were reduced in coral reef areas of the IndoPacific region with neighboring intact seagrass beds.

We were interested whether this effect is of general nature, and would also apply to temperate seagrasses of the northern hemisphere (Boström et al. 2014). Hence, we studied the effects of a leaf canopy of the widespread temperate seagrass Zostera marina (eelgrass) on water column abundance of Vibrio spp. bacteria, an abundant and diverse bacterial group thriving in marine waters that are generally favored by global warming and seawater freshening (BakerAustin et al. 2012; Oberbeckmann et al. 2012). This applies particularly to our study region, the Baltic Sea, where Vibrio spp. abundances have already increased in the past decades due to sea surface temperature increase (Baker-Austin et al. 2012; Gyraite et al. 2019), with a rate that is substantially higher than the predicted global ocean warming (Reusch 
et al. 2018). It is, therefore, concerning that environmental conditions are predicted to become even more conducive to further expansion of Vibrio due to the freshening of the brackish water body (Meier et al. 2006; Meier and Saraiva 2020). Alarmingly, the incidence of severe Vibrio vulnifcus infections upon swimming or other contact with Baltic Sea waters has increased in recent years (Baker-Austin et al. 2016) which has sparked considerable media interest and potentially endangers touristic activities and revenues in the area (Gyraite et al. 2019).

Here, we present first pilot data on the abundance of bacterial groups belonging to the Vibrio spp. group in temperate seagrass beds of the south-western Baltic Sea based on a robust plate counting approach. We hypothesized that, analogous to tropical seagrass beds (Lamb et al. 2017), Zostera marina (eelgrass) meadows would reduce the bacterial abundance in seawater within the seagrass leaf canopy compared to adjacent sand flats. To this end, we designed a sampling program in situ by SCUBA at five locations in the southwestern Baltic Sea and assessed the bacterial abundance in seawater from inside and outside the leaf canopy at each site with an unselective, and a Vibrio-specific culture medium.

\section{Materials and methods}

We sampled defined microhabitats associated at locations in the south-western Baltic Sea that harbor extensive eelgrass Zostera marina beds. These are typically interspersed with larger sandy areas. At each site, two un-vegetated and two vegetated areas were sampled in duplicates in September 2019 except for site "Gelting" where only one isolated patch of $20 \mathrm{~m}^{2}$ survived a recent die-off event in 2015 due to as yet unidentified causes (Table 1). Sampling points were at least $5 \mathrm{~m}$ away from the vegetation edge, again with the exception of the within-vegetation sampling point in Gelting that was only $2.5 \mathrm{~m}$ inside the remaining patch. In general, shoot densities in the south-western Baltic vary between 240 and 310 leaf shoots $\mathrm{m}^{-2}$, and shoot heights are $50-85 \mathrm{~cm}$ (Reusch et al. 1994; Munkes et al. 2015). Three sites ("Kiekut",
"Möltenort" and "Falckenstein") are in front of recreational beaches. During each sampling, water temperatures and salinities were measured with a handheld WTW instrument in $30-50 \mathrm{~cm}$ depth.

Water samples were taken by SCUBA at a water depth between 0.4 and $3.4 \mathrm{~m}$. The depth was dictated by the presence of a dense seagrass canopy which varied at each chosen site. In the western Baltic Sea, no lunar tides exist while wind-driven tides did not occur at the time of sampling. Divers approached the dedicated sampling points against the prevailing current which was determined by slowly releasing seawater blobs stained with uranine $\left(0.5 \mathrm{~g} \mathrm{~L}^{-1}\right)$ (Reusch and Williams 1999). Typical current speeds in the area were between $1-5 \mathrm{~cm} \mathrm{~s}^{-1}$. Water samples were taken by gentle suction of $100 \mathrm{~mL}$ water using sterile syringes $20 \mathrm{~cm}$ above the sediment bottom. Great care was taken that during suction sampling, SCUBA divers were well in buoyancy and did not stir up sediment or material from the seagrass blades. Syringes were flushed three times underwater before the final sample suction.

Water samples were transferred to coolers at $4{ }^{\circ} \mathrm{C}$ within $6 \mathrm{~h}$ to the laboratory whereupon gentle mixing, for each sample, aliquots of 250 and $100 \mu \mathrm{L}$ of seawater were plated onto Vibrio selective agar (CHROMagar_vibrio ${ }^{\text {TM }}$, Chromagar Ltd. Paris, France; (Hara-Kudo et al. 2001)) and onto marine broth agar, respectively. Upon a 4-day incubation at $25^{\circ} \mathrm{C}$ for the CHROMagar medium, and $30{ }^{\circ} \mathrm{C}$ for marine broth, colonies were counted. Colonies growing on CHROMagar can be assigned to the three major Vibrio spp. subtypes $V$. parahaemolyticus, $V$. vulnificus/cholerae, and $V$. alginolyticus via colony color (Hara-Kudo et al. 2001).

Count data of all four response variables (3 Vibrio subtypes/marine broth colonies) were square-root transformed to improve variance homogeneity (Sokal and Rohlf 1995), while approximate normality was checked using residual plots. To accommodate the inflation of type 1-errors owing to multiple testing (Johnson and Field 1993), count data were first subjected to multivariate analysis of variance (MANOVA, mean effect test) to test for an overall effect of vegetation absence/presence (hereafter "vegetation")

Table 1 Sampling sites in the south-western Baltic Sea in September 2019

\begin{tabular}{|c|c|c|c|c|c|c|c|c|}
\hline \multirow[b]{2}{*}{ Site } & \multirow[b]{2}{*}{ Region } & \multirow[b]{2}{*}{ Date } & \multicolumn{2}{|c|}{ Geographic coordinates } & \multicolumn{2}{|c|}{ Water depth (m) } & \multicolumn{2}{|c|}{ Environmental conditions } \\
\hline & & & Lat $(\mathrm{N})$ & Long (E) & Zostera & sand & Salinity (psu) & $\begin{array}{l}\text { Water } \\
\text { temperature } \\
\left({ }^{\circ} \mathrm{C}\right)\end{array}$ \\
\hline Gelting & Flensburg Fjord & 24 Sep & 54.7617 & 9.8789 & 0.9 & 0.6 & 22.1 & 15 \\
\hline Kiekut & Eckenförde Bay & 4 Sep & 54.4485 & 9.8708 & $1.9-2.1$ & $0.9-1.0$ & 18 & 18.5 \\
\hline Falckenstein & Kiel Fjord & 9 Sep & 54.3936 & 10.1923 & $1.1-3.3$ & $0.6-0.9$ & 15.3 & 18 \\
\hline Möltenort & Kiel Fjord & 19 Sep & 54.3816 & 10.2007 & $1.1-3.1$ & $0.8-1.1$ & 16.6 & 15 \\
\hline Heiligenhafen & Kiel Bight & $11 \mathrm{Sep}$ & 54.3805 & 11.0077 & $0.8-3.3$ & $0.5-2.3$ & 14.3 & 16.8 \\
\hline
\end{tabular}


on bacterial and Vibrio spp. abundance. A calculation of a cross-correlation matrix explored the covariance among the 4 response variables. Subsequently, all 4 response variables were also tested in univariate analyses of variance (ANOVA) with type-III error estimation separately. At all sites, more than one vegetated or non-vegetated subarea, respectively, was sampled as seagrass grows typically in zones parallel to shore interspersed with sandy areas. In an initial step, we used nested analysis of variance to check for any influence of subarea as "subarea (vegetation vs. no vegetation)"-effect. If this was not the case, error terms can be pooled and all sampled sub-replicates would be treated as true replicates sampled within or outside vegetation at each site, respectively. For all univariate response variables (colony-forming units $=\mathrm{cfu}$ marine broth bacteria/all Vibrio subgroups) the nested factor was not significant (all $P>0.11$ ). Based on recommendations in Underwood (1997), we therefore pooled error terms of the nested effect and the residuals to test for the main effects "vegetation" and "site" and their interaction. Since the habitat types were partially confounded with water depth, we also tested the effect of the covariate "depth" on any of the 4 bacterial abundances in an ANCOVA model. All statistical analyses were conducted in JMP v. 10.0 (Statsoft Inc. 2012).

\section{Results and discussion}

Overall Vibrio spp. counts (as colony-forming units, cfu $250 \mu \mathrm{l}^{-1}$ ) varied between 32.3 and 66.1 among all sites, while general bacterial counts (marine broth) were substantially higher and ranged between 88.6 and $179.9 \mathrm{cfu}$ $100 \mu^{-1}$. Colonies indicative of $V$. parahaemolyticus were rare regardless of the presence of seagrass vegetation across sites (mean \pm SD $1.97 \pm 2.02 \mathrm{cfu} 250 \mu \mathrm{l}^{-1}$ ), followed in abundance by the $V$. vulnificus group and the most abundant $V$. alginolyticus group $\left(15.0 \pm 9.9\right.$ and $31.3 \pm 18.2 \mathrm{cfu} 250 \mu \mathrm{l}^{-1}$, respectively). An overall MANOVA revealed that both main factors "site" and "vegetation presence/absence" had significant effects on the overall abundance on the 4 bacterial groups tested (3 Vibrio subtypes/general marine bacteria on marine broth; Pillai-trace test statistic, all $P<0.01$; Supplementary Table 1 ). The abundance of bacteria on marine broth was only weakly correlated with overall and specific Vibrio group abundances (Supplementary Table S2). The abundance of the three Vibrio subtypes among themselves correlated only moderately with one another (all $|R|<0.23$; Supplementary Table S2).

Upon the statistically significant MANOVA, we proceeded with univariate tests to examine the influence of "site" and "vegetation" on the abundance of general marine bacteria and the Vibrio subgroups separately. Abundances based on colony counts on marine broth revealed a significant reduction within the vegetation (-30\%; main effect vegetation, Fig. 1A, Table 2). For bacteria counted on marine broth, there was also a strong "site * vegetation presence/absence"-interaction mainly driven by the site "Kiekut" where the bacterial abundance was slightly higher within the vegetation.

In accordance with the results of general bacterial abundance, we found that across all sites the presence of vegetation reduced the abundance of all Vibrio spp. by $39 \%$ compared to adjacent non-vegetated area, a reduction that was slightly higher compared to bacteria on marine broth. When broken down into subtypes, Vibrio spp. abundance was reduced by 63,61 and 23\% (V. parahaemolyticus / vulnificus /alginolyticus respectively), (Fig. 1B-D). While the main effect "vegetation" was significant for all Vibrio subtypes (all $P_{\text {veg }}<0.007$; Table 2), we also found a marked effect of "site" on all bacterial abundances, suggesting

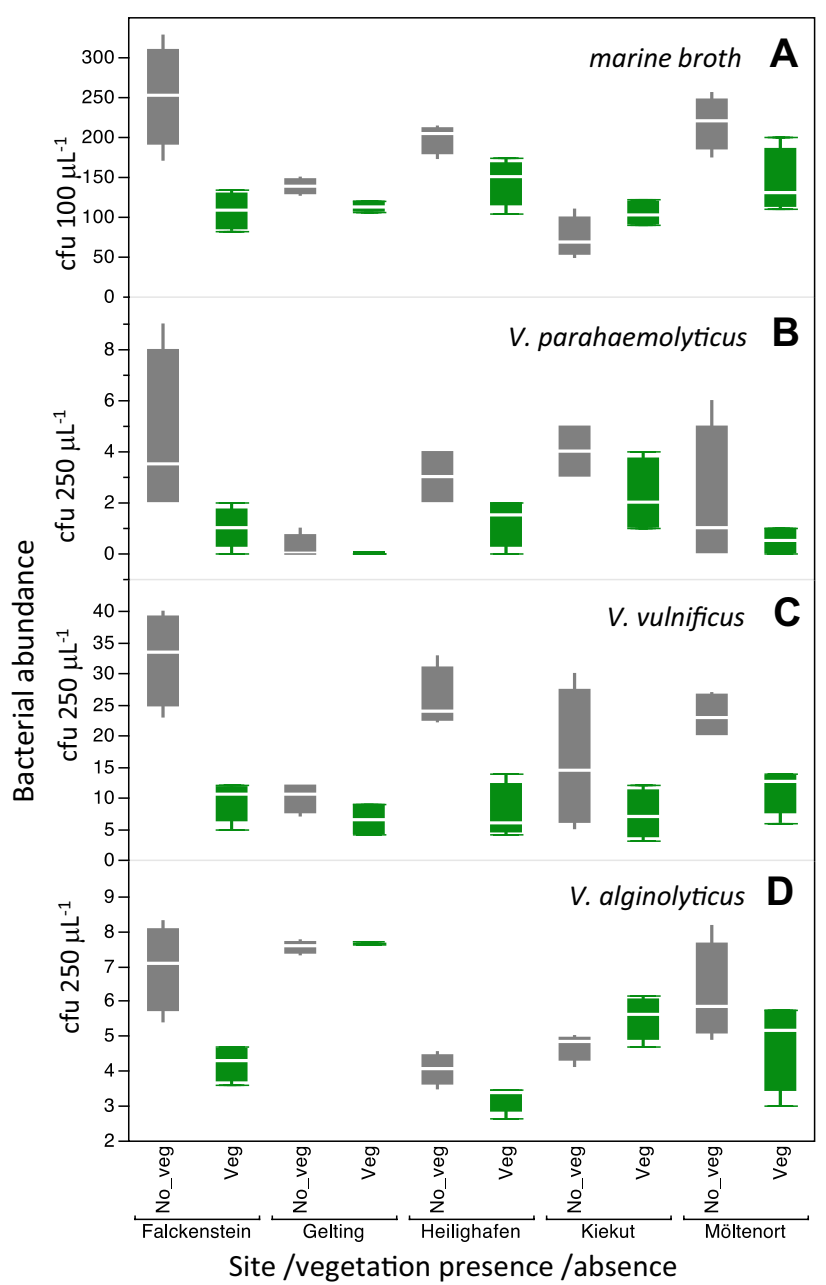

Fig. 1 Mean abundance $( \pm 1 \mathrm{SD}, N=4)$ of Vibrio spp. assessed as plate counts of colony forming units (cfu) at 5 sites in the southwestern Baltic Sea. For details on sampling sites see Table 1, for statistical analysis Table 2 
Table 2 Results of two-way type-III ANOVAs on bacterial abundance as function of sampling site and vegetation presence/absence

\begin{tabular}{llrrrrc}
\hline Response variable & Effect & $d f$ & $S Q$ & $M S$ & $F$ & $P$ \\
\hline Bacteria marine broth & Site & 4 & 90.31 & 22.57 & 14.13 & $<.0001$ \\
& Vegetation & 1 & 34.89 & 34.89 & 21.83 & $<.0001$ \\
& Site* veg & 4 & 47.24 & 11.81 & 8.346 & $<.0001$ \\
& Error & 28 & 44.75 & 1.598 & & \\
all Vibrio spp. & Site & 4 & 25.74 & 6.434 & 10.83 & $<.0001$ \\
& Vegetation & 1 & 28.32 & 28.32 & 47.68 & $<.0001$ \\
& Site* veg & 4 & 19.57 & 4.892 & 8.236 & 0.0002 \\
V. parahaemolyticus & Error & 28 & 16.63 & 0.5940 & & \\
& Site & 4 & 10.40 & 2.599 & 6.293 & 0.001 \\
& Vegetation & 1 & 3.680 & 3.680 & 8.902 & $<.0001$ \\
& Site* veg & 4 & 0.8444 & 0.2111 & 0.5112 & 0.728 \\
& Error & 28 & 11.564 & 0.4130 & & \\
V. vulnificus/cholerae & Site & 4 & 10.79 & 2.697 & 4.904 & 0.004 \\
& Vegetation & 1 & 25.38 & 25.38 & 46.15 & $<.0001$ \\
& Site* veg & 4 & 4.776 & 1.194 & 2.171 & 0.0983 \\
& Error & 28 & 15.40 & 0.5499 & & \\
& Site & 4 & 51.57 & 12.89 & 18.54 & $<.0001$ \\
& Vegetation & 1 & 5.976 & 5.976 & 8.595 & 0.007 \\
& Site* veg & 4 & 14.47 & 3.618 & 5.203 & 0.0029 \\
& Error & 28 & 19.47 & 0.6953 & & \\
\hline
\end{tabular}

$d f$ degrees of freedom, $S Q$ sums of squares, $M S$ mean squares, $F F$-ratio regional heterogeneities in overall bacterial abundances at the km-scale (Table 2). Because site "Gelting" possessed only one remaining $Z$. marina patch of limited size we also analyzed Vibrio spp. abundance without that site. This changed the statistical test results only marginally (2-factorial ANOVA, sqrt transformed Vibrio spp. counts, $\left.F_{1,25}=28.4, P_{\text {vegetation }}<0.001\right)$.

The reduction in bacterial abundance was consistent across most of the sites. Specifically, despite significant overall site-differences in abundance, there was no interaction detectable among both main factors for the $V$. vulnificus/ cholerae subtype (Fig. 1C). For the 2 other Vibrio subtypes (V. alginolyticus and parahaemolyticus) there was a significant "site*vegetation"-interaction. For V. parahaemolyticus, above statistical interaction reflected a reduction for this Vibrio subtype that varied strongly among sites, while the general direction of bacterial reduction inside the leaf canopy was similar across all 5 sites (Fig. 1B). This was not the case in $V$. alginolyticus, where a closer inspection revealed that this effect was due to the site "Kiekut" where the direction of effect reversed and we observed a higher abundance of bacteria within the seagrass canopy (Fig. 1D). We tested and confirmed this by excluding that site from the data set which let the statistical interaction disappear (analysis not shown).

In an ANCOVA model, we found a negative effect of water depth only on the abundance of marine broth bacteria $(r=-0.77 \pm 0.26 \mathrm{SE})$ on sqrt-transformed bacterial colony counts $(P=0.0081)$. In contrast, all statistical models on overall and Vibrio subtype abundances did not reduce the unexplained error variance by including the predictor variable "water depth" into the ANCOVA (all $P>0.13$, analysis not shown).

To the best of our knowledge, these are the first data on temperate seagrass beds that show a reduction in the abundance of potentially harmful bacteria of the Vibrio spp. group, consistent with earlier findings for tropical seagrasses (Lamb et al. 2017). Overall, the effects on all Vibrio spp. were consistent with the data on bacterial counts obtained on a general marine broth medium. An exception was the potentially harmful group of $V$. vulnificus/cholerae, where the mean reduction in cfu was with $63 \%$ the strongest in samples inside the leaf canopy compared to the abundance found in the water column above non-vegetated sandy areas outside. A similarly marked reduction was observed for $V$. parahaemolyticus, yet since the overall abundance of this Vibrio subtype was only $\sim 2 \mathrm{cfu} 250 \mu \mathrm{l}^{-1}$, these data have to be interpreted with caution. While the assignment to Vibrio subtypes based on colony color was unambiguous, further studies characterize colonies via $16 \mathrm{~S}$ rDNA sequencing to further examine their exact taxonomic composition.

Marked site effects as well as interactions of "site" with Zostera presence on bacterial abundance suggest heterogeneity of processes at a $\mathrm{km}$-scale, hence our data should be taken as pilot data that would need confirmation in a more exhaustive spatio-temporal sampling design. Note that in the 
south-western Baltic, salinity values (Table 1) vary strongly with actual wind conditions. Hence, to examine salinity effects on Vibrio spp. abundance, more frequent temporal sampling would be needed throughout the year. A denser temporal sampling would also be needed to better cover the temperature dependence. Nevertheless, owing to the growing importance of Vibrio spp. for tourism and human health during summer months in rapidly warming northern European seas (Bier et al. 2015; Gyraite et al. 2019) we consider this data set worthwhile for publication to motivate further studies.

Similar to the analogous role of tropical seagrass beds (Lamb et al. 2017), the underlying mechanism of seagrass on surrounding water column bacteria is currently elusive. Possible non-exclusive mechanisms include (i) a simple increase of sedimentation rate through hydrodynamic attenuation of the canopy that would reduce particle load (Fonseca et al. 1982; Nowell and Jumars 1984; Worcester 1995) and hence, bacteria associated with organic particles, (ii) filter feeding of fauna associated with $Z$. marina beds that removes plankton known as reservoirs for Vibrio or directly consumes bacteria (Bradley and Kenneth 2001; González-Ortiz et al. 2014), or (iii) allelopathic chemicals exuding from $Z$. marina leaves (Papazian et al. 2019). It is well established that the first two effects contribute to enhancement of water clarity in seagrass beds (Adams et al. 2016). The approximately similar magnitude of reduction of bacterial colonies growing on marine broth versus CHROMagar (indicative of Vibrio spp.) supports the hypothesis that the reduction is mainly non-selective with respect to the bacterial groups. On the other hand, for the subtype $V$. vulnificus, the reduction was even $63 \%$. In conclusion, further study is required to verify mechanisms and possible selectivity towards certain bacterial groups. Regardless of the specific mechanism, it is clear that the seagrass holobiont alters the microbiological composition in its vicinity (Trevathan-Tackett et al. 2019), and our data are in line with these predictions.

Nature based solutions (Gattuso et al. 2018; Seddon et al. 2020), such as the manipulation of microbiomes (TrevathanTackett et al. 2019) or the large-scale restoration of macroalgae and seagrasses (Gattuso et al. 2018) have recently been proposed to combat various negative effects of global change and human perturbation on coastal ecosystems. Achievable goals include an improvement of water quality and the enhancement of carbon sequestration. Our study provides another example as to how the protection and possible restoration of seagrass beds (Tan et al. 2020) may help sustaining as yet understudied ecosystem services such as the suppression of bacterial load. Along with already known effects on biodiversity enhancement and improvement of water quality seagrasses may contribute to preserve the potential of coastal regions to provide tourism services without risking the health of humans visiting the ocean (Bier et al. 2015) or consuming local seafood (Rippey 1994).

Supplementary Information The online version contains supplementary material available at https://doi.org/10.1007/s00227-021-03963-3.

Acknowledgements Ann-Cathrin Fabricius and Vincent Fey assisted with the laboratory work, while Marlene Beer helped during field sampling. The assistance of the research divers Christian Howe, Florian Huber and Jana Ulrich in sampling acquisition is gratefully acknowledged.

Author's contributions TR, PS and RK conceived the study, PS along with TR organized and conducted the sampling, DG and SMM conducted the laboratory analysis with advice from KB and UH, TR wrote the manuscript, all authors discussed the results, and commented and edited the manuscript.

Funding Open Access funding enabled and organized by Projekt DEAL. This work was partly funded by the State Agency for Agriculture, Environment, and Rural Areas Schleswig-Holstein (LLUR), and by the German Helmholtz-Association, program oriented funding IV, Topic 6 (Marine Life).

\section{Declarations}

Conflict of interest The authors declare that the research was conducted in the absence of any commercial or financial relationships that could be construed as a potential conflict of interest

Ethical approval All applicable international, national, and/or institutional guidelines for the care and use of organisms were followed.

Data availability Original data are available in Supplementary Table S3.

Code availability NA.

Open Access This article is licensed under a Creative Commons Attribution 4.0 International License, which permits use, sharing, adaptation, distribution and reproduction in any medium or format, as long as you give appropriate credit to the original author(s) and the source, provide a link to the Creative Commons licence, and indicate if changes were made. The images or other third party material in this article are included in the article's Creative Commons licence, unless indicated otherwise in a credit line to the material. If material is not included in the article's Creative Commons licence and your intended use is not permitted by statutory regulation or exceeds the permitted use, you will need to obtain permission directly from the copyright holder. To view a copy of this licence, visit http://creativecommons.org/licenses/by/4.0/.

\section{References}

Adams MP, Hovey RK, Hipsey MR, Bruce LC, Ghisalberti M, Lowe RJ, Gruber RK, Ruiz-Montoya L, Maxwell PS, Callaghan DP, Kendrick GA, O'Brien KR (2016) Feedback between sediment and light for seagrass: where is it important? Limnol Oceanogr 61:1937-1955. https://doi.org/10.1002/lno.10319 
Baker-Austin C, Trinanes JA, Taylor NGH, Hartnell R, Siitonen A, Martinez-Urtaza J (2012) Emerging Vibrio risk at high latitudes in response to ocean warming. Nat Clim Chang 3:73-77

Baker-Austin C, Trinanes JA, Salmenlinna S, Löfdahl M, Siitonen A, Taylor NGH, Martinez-Urtaza J (2016) Heat wave-associated vibriosis, Sweden and Finland, 2014. Emerg Infect Dis 22:12161220. https://doi.org/10.3201/eid2207.151996

Bier N, Jäckel C, Dieckmann R, Brennholt N, Böer SI, Strauch E (2015) Virulence profiles of Vibrio vulnificus in German coastal waters, a comparison of North Sea and Baltic Sea isolates. Int J Environ Res Public Health 12:15943-15959. https://doi.org/10. 3390/ijerph121215031

Boström C, Baden S, Bockelmann A-C, Dromph K, Fredriksen S, Gustafsson C, Krause-Jensen D, Möller T, Nielsen SL, Olesen B, Olsen J, Pihl L, Rinde E (2014) Distribution, structure and function of Nordic eelgrass (Zostera marina) ecosystems: implications for coastal management and conservation. Aquat Conserv Mar Freshwat Ecosyst 24:410-434. https://doi.org/10.1002/aqc.2424

Bradley JP, Kenneth LH Jr (2001) Positive interactions between suspension-feeding bivalves and seagrass $<$ a facultative mutualism. Mar Ecol Prog Ser 213:143-155

Fonseca MS, Fisher JS, Zieman JC, Thayer GW (1982) Influence of seagrass, Zostera marina L., on current flow. Est Coast Shelf Sci 15:351-364

Fourqurean JW, Duarte CM, Kennedy H, Marbà N, Holmer M, Mateo MA, Apostolaki ET, Kendrick GA, Krause-Jensen D, McGlathery KJ (2012) Seagrass ecosystems as a globally significant carbon stock. Nat Geosci 5:505-509

Gattuso J-P, Magnan AK, Bopp L, Cheung WWL, Duarte CM, Hinkel J, McLeod E, Micheli F, Oschlies A, Williamson P, Billé R, Chalastani VI, Gates RD, Irisson J-O, Middelburg JJ, Pörtner H-O, $\mathrm{Rau}$ GH (2018) Ocean solutions to address climate change and its effects on marine ecosystems. Front Mar Sci 5:337

González-Ortiz V, Egea LG, Jiménez-Ramos R, Moreno-Marín F, Pérez-Lloréns JL, Bouma TJ, Brun FG (2014) Interactions between seagrass complexity, hydrodynamic flow and biomixing alter food availability for associated filter-feeding organisms. PLoS ONE 9:e104949. https://doi.org/10.1371/journal.pone. 0104949

Gyraite G, Katarzyte M, Schernewski G (2019) First findings of potentially human pathogenic bacteria Vibrio in the south-eastern Baltic Sea coastal and transitional bathing waters. Mar Pollut Bull 149:110546. https://doi.org/10.1016/j.marpolbul.2019.110546

Hara-Kudo Y, Nishina T, Nakagawa H, Konuma H, Hasegawa J, Kumagai $S$ (2001) Improved method for detection of Vibrio parahaemolyticus in seafood. Appl Environ Microbiol 67:5819. https://doi. org/10.1128/AEM.67.12.5819-5823.2001

Heckwolf MJ, Peterson A, Jänes H, Horne P, Künne j, Liversage K, Sajeva M, Reusch TBH, Kotta J, (2021) From ecosystems to socio-economic benefits: a systematic review of coastal ecosystem services in the Baltic Sea. Sci Total Environ 755:142565

Hemminga MA, Duarte CM (2000) Seagrass ecology. Cambridge University Press, Cambridge

Johnson CR, Field CA (1993) Using fixed-effects model multivariate analysis of variance in marine biology and ecology. Oceanogr Mar Biol Ann Rev 31:177-221

Lamb JB, van de Water JAJM, Bourne DG, Altier C, Hein MY, Fiorenza EA, Abu N, Jompa J, Harvell CD (2017) Seagrass ecosystems reduce exposure to bacterial pathogens of humans, fishes, and invertebrates. Science 355:731-733

Meier HEM, Saraiva S (2020) Projected oceanographical changes in the Baltic Sea until 2100. Oxford University Press

Meier HEM, Kjellstro E, Graham LP (2006) Estimating uncertainties of projected Baltic Sea salinity in the late 21 st century. Geophys Res Lett 33:L15705-L15704
Munkes B, Schubert PR, Karez R, Reusch TBH (2015) Experimental assessment of critical anthropogenic sediment burial in eelgrass Zostera marina. Mar Poll Bullet 100:144-153

Nowell ARM, Jumars PA (1984) Flow environments of aquatic benthos. Ann Rev Ecol Syst 15:303-328

Oberbeckmann S, Fuchs BM, Meiners M, Wichels A, Wiltshire KH, Gerdts G (2012) Seasonal dynamics and modeling of a Vibrio community in coastal waters of the North Sea. Microb Ecol 63:543-551. https://doi.org/10.1007/s00248-011-9990-9

Papazian S, Parrot D, Burýšková B, Weinberger F, Tasdemir D (2019) Surface chemical defence of the eelgrass Zostera marina against microbial foulers. Sci Rep 9:3323. https://doi.org/10.1038/ s41598-019-39212-3

Reusch TBH, Williams SL (1999) Macrophyte canopy structure and the success of a non-indigenous bivalve. Oikos 84:398-416

Reusch TBH, Chapman ARO, Gröger JP (1994) Blue mussels (Mytilus edulis) do not interfere with eelgrass (Zostera marina) but fertilize shoot growth through biodeposition. Mar Ecol Prog Ser 108:265-282

Reusch TBH, Dierking J, Andersson HC, Bonsdorff E, Carstensen J, Casini M, Czajkowski M, Hasler B, Hinsby K, Hyytiäinen K, Johannesson K, Jomaa S, Jormalainen V, Kuosa H, Kurland S, Laikre L, MacKenzie BR, Margonski P, Melzner F, Oesterwind D, Ojaveer H, Refsgaard JC, Sandström A, Schwarz G, Tonderski K, Winder M, Zandersen M (2018) The Baltic Sea as a time machine for the future coastal ocean. Sci Adv 4:8195. https://doi.org/10. 1126/sciadv.aar8195

Rippey SR (1994) Infectious diseases associated with molluscan shellfish consumption. Clin Microbiol Rev 7:419-425. https://doi.org/ 10.1128/CMR.7.4.419

Seddon N, Chausson A, Berry P, Girardin CAJ, Smith A, Turner B (2020) Understanding the value and limits of nature-based solutions to climate change and other global challenges. Philos Trans R Soc B Biol Sci 375:20190120. https://doi.org/10.1098/rstb. 2019.0120

Sokal RS, Rohlf FJ (1995) Biometry. W. H. Freeman and Company, San Francisco

Tan YM, Dalby O, Kendrick GA, Statton J, Sinclair EA, Fraser MW, Macreadie PI, Gillies CL, Coleman RA, Waycott M, van Dijk K-j, Vergés A, Ross JD, Campbell ML, Matheson FE, Jackson EL, Irving AD, Govers LL, Connolly RM, McLeod IM, Rasheed MA, Kirkman H, Flindt MR, Lange T, Miller AD, Sherman CDH (2020) Seagrass restoration is possible: insights and lessons from Australia and New Zealand. Front Mar Sci 7:617

Trevathan-Tackett SM, Sherman CDH, Huggett MJ, Campbell AH, Laverock B, Hurtado-McCormick V, Seymour JR, Firl A, Messer LF, Ainsworth TD, Negandhi KL, Daffonchio D, Egan S, Engelen AH, Fusi M, Thomas T, Vann L, Hernandez-Agreda A, Gan HM, Marzinelli EM, Steinberg PD, Hardtke L, Macreadie PI (2019) A horizon scan of priorities for coastal marine microbiome research. Nat Ecol Evol 3:1509-1520. https://doi.org/10.1038/ s41559-019-0999-7

Underwood AJ (1997) Experiments in ecology. Cambridge University Press, Cambridge

Worcester SE (1995) Effects of eelgrass beds on advection and turbulent mixing in low current and low shoot density environments. Mar Ecol Prog Ser 126:223-232

Publisher's Note Springer Nature remains neutral with regard to jurisdictional claims in published maps and institutional affiliations. 